\title{
Analisis Pengaruh Dimensi Fraud Triangle Dalam Kebijakan Pencegahan Fraud Terhadap Program Jaminan Kesehatan Nasional di RSUP Nasional Cipto Mangunkusumo
}

\author{
Hasan Sadikin', Wiku Adisasmito \\ ${ }^{1}$ Fakultas Kesehatan Masyarakat Universitas Indonesia, \\ ${ }^{2}$ Departemen Administrasi Kebijakan Kesehatan, Fakultas Kesehatan Masyarakat Universitas Indonesia \\ Contact: hasansadikin91@gmail.com \\ Reviewed October 20, 2016, and accepted on November 5, 2016
}

\begin{abstract}
Abstrak
Jaminan Kesehatan Nasional (JKN) yang diselenggarakan oleh Badan Jaminan Sosial (BPJS) Kesehatan telah mulai dilaksanakan dari 1 Program Asuransi Kesehatan di Indonesia Januari 2014. Pelaksanaan program asuransi nasional menemukan risiko. Risiko kejadian fraud (kecurangan) di Indonesia sangat tinggi. Namun,risiko kejadian fraud masih sulit untuk diidentifikasi. Hal tersebut didukung oleh kurangnya kesadaran semua pihak baik dari pasien, provider dan perusahaan asuransi walaupun tindakan tersebut sangat terasa adanya. Penipuan kesehatan merupakan ancaman serius bagi seluruh dunia, yang menyebabkan penyalahgunaan keuangan sumber daya yang langka dan dampak negatif pada akses kesehatan, infrastruktur, dan determinan sosial kesehatan. Penipuan kesehatan dikaitkan dengan meningkatnya biaya kesehatan yang terjadi di Amerika Serikat. Penelitian ini untuk menganalisis tentang pengaruh dimensi fraud triangle dalam kebijakan pencegahan fraud terhadap program Jaminan Kesehatan Nasional yang merupakan alasan untuk penipuan kesehatan. Penelitian ini menggunakan pendekatan kualitatif. Teknik pengumpulan data berupa pedoman wawancara, alat perekam, arsip tertulis dan dokumen. Hasil penelitian mendapatkan analisis tekanan, kesempatan, dan rasionalisasi terhadap risiko kejadian fraud dan menyajikan contoh bagaimana kebijakan telah berdampak di RSUP Nasional DR Cipto Mangunkusumo. Tesis ini kemudian akan memberikan saran tentang bagaimana mencegah penipuan kesehatan masa depan untuk mengurangi pengeluaran kesehatan dan penggunaan sumber daya untuk kepentingan RSUP Nasional DR Cipto Mangunkusumo.
\end{abstract}

Kata kunci: kecurangan, kebijakan pencegahan fraud, fraud jaminan kesehatan nasional

\begin{abstract}
The National Health Insurance (JKN) held by the Social Security Agency (BPJS) Health started to be implemented from 1 Indonesia's Health Insurance Program in January 2014. The implementation of a national insurance program found the risk. The risk of occurrence of fraud in Indonesia is very high but it is still difficult to identify its risk. This is supported by the lack of awareness of all parties, including patients, providers and insurance companies although such actions exists. Health fraud is a serious threat to the entire world, which led to financial abuse of scarce resources and the negative impact on access to health care, infrastructure, and social determinants of health. Health fraud is associated with increased health care costs in the United States. This study was to analyze the influence of the dimensions of the fraud triangle in fraud prevention policies towards the National Health Insurance program which is the reason for health fraud. This study used a qualitative approach. Data collection techniques such as interview guides, recorders, written records and documents. The study reported stress analysis, opportunity, and rationalization of the risk of fraud incident and presents examples of how policy has an impact on the National Hospital Dr. Cipto Mangunkusumo. This thesis will then provide advice on how to prevent future fraudulent health to reduce health spending and use of resources for the benefit of the National Hospital Dr. Cipto Mangunkusumo.
\end{abstract}

Keywords: Fraud, fraud prevention policies, fraud in National Health Insurance.

\section{Pendahuluan}

Pada tanggal 1 Januari 2014 program Jaminan Kesehatan Nasional mulai berjalan di Indonesia. Seiring dengan meningkatnya jumlah peserta Jaminan Kesehatan Nasional dan fasilitas kesehatan yang memberikan pelayanan, semakin banyak kritik dari berbagai pihak, salah satunya dari provider jaminan kesehatan nasional (puskesmas, rumah sakit), prihal dugaan terjadinya fraud (Yaslis, 2015). Dugaan akan tindakan fraud tidak hanya terjadi di Indonesia yang belum tertata rapi sistem pelayanan kesehatan maupun sistem pembiayaannya. Dugaan fraud dalam sistem pelayanan kesehatan juga berdampak di seluruh dunia. Di Negara Amerika yang merupakan negara maju, dilaporkan oleh General Accounting Office (GAO) pada tahun 1990, klaim indikasi kejadian fraud tercatat berkisar US\$ 100 Milyar atau senilai10\% dari total biaya kesehatan setahun. (data, 2002). Bahkan pada saat terjadi peningkatan peserta, di situ terdapat celah dalam penggunaan asuransi kesehatan dengan harga mengejutkan, yakni diperkirakan antara US\$ 67 Milyar dan 226 Milyar \$ per tahun(Anonymous, 2009). Menurut perkiraan Biro Investigasi Federal (BIF), penipuan kesehatan biaya pem- 
bayar pajak Amerika lebih dari US \$80 miliar setahun (Aldrich, Crowder, dan Benson 2014). Mendeteksi penipuan asuransi kesehatan adalah penting dan tantangan yang sulit (Shi et al., 2016). Banyak dugaan kecurangan - kecurangan yang dilakukan di pelayanan kesehatan di seluruh Indonesia terkait sistem dan pelayanan, seperti merubah diagnosis utama maupun membuat diagnosis tambahan sehingga mendapatkan tarif yang besar. Berbagai isu fraud pada pelayanan kesehatan, paling tidak menurut Charles terdiri dari sepuluh skema, di antaranya mengklaim pelayanan yang tidak pernah diberikan, mengklaim layanan yang tidak dapat ditanggung asuransi, sebagai layanan yang ditanggung asuransi, memalsukan waktu layanan, memalsukan lokasi layanan, memalsukan pemberi layanan, mengklaim tagihan yang seharusnya dibayar pasien, pelaporan diagnosis dan prosedur yang salah, pelayanan yang berlebihan, korupsi (sogokan), dan peresepan obat yang tidak perlu” (Charles, 2015).

Kegagalan mencegah dan mendeteksi kecurangan mempunyai konsekuensi serius bagi organisasi (Coffin, 2003). Di AS, biaya-biaya keuangan yang dihubungkan dengan kecurangan karyawan diperkirakan sekitar US\$50 milyar tiap tahun. Tahun 2006, Association of Certified Fraud Examiners (ACFE) meneliti tentang Occupational Fraud and Abuse yang terjadi di Amerika Serikat dalam rentang waktu 2004 - 2006. Dalam penelitian tersebut, disebutkan bahwa dalam rentang waktu dua tahun terdapat 1.134 kasus kecurangan yang diinvestigasi oleh anggota ACFE, dengan rata-rata kerugian US\$159 milyar. ACFE memperkirakan bahwa perusahaan-perusahaan di Amerika Serikat mengalami kerugian sebesar 5\% dari pendapatannya karena ulah pihak yang tidak bertanggung jawab. Bila nilai kerugian tersebut dikalikan dengan Gross Domestic Product tahun 2006, kerugian yang ditimbulkan akibat kecurangan adalah sebesar US $\$ 652$ milyar (www.acfe.com, diunduh tanggal 19 April 2016 ).

Pihak- pihak yang melakukan fraud adalah peserta (pasien), pemberi pelayanan kesehatan (provider), perusahaan asuransi (payer) (Ginting, 2007). Melihat definisi di atas, dapat diindikasikan bahwa tindakan fraud merupakan unsur kesengajaan dan tindakan merugikan pihak lain dari pelaku sehingga UU Pidana bisa diberlakukan. Pada dasarnya, Jaminan Kesehatan Nasional (JKN) memberikan manfaat yang bersifat konprehensif (Thabrany, 2014). Dibalik tujuan mulia JKN, potensi fraud yang mungkin terjadi perlu diidentifikasi sehingga tidak akan menimbulkan kerugian uang negara (Wiyono, 2014). Padahal pengembangan sistem kesehatan di suatu negara pada dasarnya untuk mencapai kondisi derajat kesehatan yang baik (WHO, 2000). Ancaman fraud harus disiasati dengan program yang terorganisir seperti Anti-Fraud di Inggris yang terkenal dengan The Health Insurance Counter Fraud Group (HICFG). HICFG adalah inisiatif industri untuk mencegah dan men-detect fraud dalam perawatan kesehatan dan industri asuransi kesehatan, sedangkan program yang sama di Amerika dikenal dengan The National Health Care Anti-Fraud Association (NHCAA) yang didirikan pada tahun 1985 oleh beberapa perusahaan asuransi kesehatan swasta dan pejabat pemerintah federal dan negara. NHCAA adalah satu-satunya organisasi nasional AS yang ditujukan khusus untuk memerangi penipuan perawatan kesehatan.

Di Indonesia, tindakan fraud belum bisa terdeteksi secara benar sehingga kontrol pergerakan pelayanan dan pendanaan yang dibutuhkan masih sulit dilakukan, padahal resiko fraud di Indonesia bisa dibilang sangat tinggi. Di Amerika Serikat, negara mengharuskan pembayaran klaim sesegera mungkin, sedangkan penyelidikan fraud membutuhkan waktu yang lama (Yaslis, 2003). Cara tersebut diikuti juga oleh Indonesia sehingga dengan tekanan waktu yang singkat tersebut provider dapat segera membayar klaim dan memperpendek proses penyelidikan fraud. Menurut Skousen, situasi terjadinya tindakan fraud adalah tekanan, kesempatan dan rasionalisasi yang dikenal dengan istilah fraud triangle (Skousen et al., 2009).

Untuk mendapat gambaran pengaruh dimensi fraud triangle dalam kebijakan pencegahan fraud terhadap program JKN, studi ini dilaksanakan di RSUP Nasional Cipto Mangunkusumo. RSUP Nasional Cipto Mangunkusumo merupakan rumah sakit FKRTL yang memberikan pelayanan kesehatan terhadap pasien JKN yang terdaftar di Badan Penyelenggaraan Jasa Sosial (BPJS). berdasarkan Pasal 13 FKRTL, pihak yang bekerjasama dengan BPJS kesehatan harus membangun sistem pencegahan Kecurangan JKN melalui: a. penyusunan kebijakan dan pedoman pencegahan kecurangan $\mathrm{JKN}$, b. pengembangan pelayanan kesehatan yang berorientasi kepada kendali mutu dan kendali biaya; dan c. pengembangan budaya pencegahan kecurangan JKN sebagai bagian dari tata kelola organisasi dan tata kelola klinis yang berorientasi kepada kendali mutu dan kendali biaya (Kemenkes, 2015). Kebijakan pencegahan terhadap jaminan kesehatan nasional.

\section{Metode Penelitian}

Penelitian ini merupakan penelitian kualitatif karena memahami interaksi sosial, perasaan orang lain dan memastikan kebenaran data (Sugiono, 2009). Data yang pe- 
neliti gunakan didapat melalui metode observasi, telaah dokumen dan wawancara mendalam karena penelitian sebelumnya dalam kasus fraud triangle diusulkan sebagai teori keseluruhan untuk membantu dalam membimbing pemilihan variabel (Gepp et al., 2015). Oleh karena variabel yang dipilih oleh peneliti yaitu dimensi fraud triangle, Donald D Cressey 's (1973) membuatnya lebih cocok untuk digunakan dalam penelitian ini. Informan dipilih dengan sengaja karena instrumen dalam penelitian ini adalah peneliti sendiri (human instrument), buku catatan, recorder, kamera (Sugiono, 2009). Wawancara menggunakan pedoman wawancara dimaksudkan untuk menggali lebih dalam mengenai permasalahan dengan variabel yang terus berkembang sampai tidak ditemukan lagi informasi baru. Proses analisis data dimulai dari mendeskripsikan karaktersitik informan, mengkategorisasi data untuk diringkas dalam bentuk matriks sampai pada akhirnya diperoleh kesimpulan dari data yang dianalisis. Untuk menjaga validitas data dalam penelitian ini dilakukan metode triangulasi, yang meliputi triangulasi metode, sumber dan teori.

\section{Hasil Penelitian}

Berdasarkan hasil wawancara terhadap 16 informan yang mewakili RSUP Nasional DR Cipto Mangunkusumo terhadap pengaruh fraud triangle dalam kebijakan pencegahan fraud terhadap JKN, sebagian hanya mengikuti perintah dari pimpinan yang memiliki kebijakan. Masing-masing informan mengatakan ketika ada perintah dari instansi yang berada langsung di atasnya, secara otomatis mereka harus menjalankan kebijakan tersebut.

Berdasarkan uraian di tabel 1, potensi fraud yang paling mungkin terjadi di lingkungan rumah sakit adalah terkait penyalahgunaan aset, walaupun tidak menutup kemungkinan kedua jenis fraud terjadi dan skema fraud lainnya terjadi di lingkungan rumah sakit. Apalagi ditambah dengan pandangan sebagian masyarakat yang meragukan bersihnya institusi pemerintah dari tindakan korupsi. Hal ini sejalan dengan pendapat Informan T1:

"Sebetulnya jika harus dibandingkan dengan negara yang sudah maju, Indonesia masih sangat tertinggal yah, karena untuk kebijakan fraud itu sendiri belum dibuatkan undang-undang sehingga status hukumnya masih belum jelas bagi yang melakukan tindakan fraud"

Hasil penelitian mengenai potensi tindakan fraud ini sejalan dengan penelitian yang dilakukan The Association Certified Fraud Examiners (ACFE) 2010 berdasarkan data dari 1843 kasus fraud yang terjadi di seluruh dunia antara Januari 2008 sampai dengan Desember 2009. Semua informasi didapat dari para Certified Fraud Examiners (CFEs) yang menginvestigasi kasus-kasus ini di 106 negara. Estimasi dari para CFEs, organisasi kehilangan 5\% kekayaan pada laporan keuangan akhir tahun disebabkan karena fraud.

\section{Tabel 1 Hasil Penelitian Tekanan, Kesempatan dan Rasionalisasi dalam Kebijakan Pencegahan Fraud terhadap Jaminan Kesehatan Nasional di RSUPN DR Cipto Mangunkusumo}

\begin{tabular}{lll}
\hline No Aspek & Hasil Penelitian \\
\hline \multirow{3}{*}{$1 \quad$ Tekanan } & Tekanan membuat seseorang melakukan tindakan fraud. Tekanan \\
& dapat berasal dari berbagai aspek tuntutan seperti tuntutan ekonomi \\
& atau bahkan gaya hidup. Tekanan dapat terjadi dari faktor internal \\
& maupun faktor eksternal. \\
\hline
\end{tabular}

\section{Kesempatan}

Kebijakan terhadap tindakan yang berpotensi fraud dan pengawasan RSUP Nasional DR Cipto Mangunkusumo terhadap tindakan yang berpotensi fraud. 


\section{Pembahasan}

\section{Pengaruh Tekanan Terhadap Potensi Fraud}

Terdapat banyak faktor yang menyebabkan pegawai berpotensi melakukan fraud terhadap JKN di RSUP Nasional DR Cipto Mangunkusumo. Faktor penyebab itu sendiri terdiri dari tingginya kebutuhan yang belum terpenuhi dan rendahnya gaji yang diterima yang dapat mengakibatkan karyawan melakukan tindakan yang berpotensi fraud. Selain itu, pemerintah menetapkan kenaikan gaji setiap setahun sekali. Jika kebijakannya tidak berubah, apabila pemimpin menilai pekerjaan pegawai selama setahun tidak memuaskan (penilaian indeks kinerja individu) maka tidak menaikan gaji (remonerasi). Kebijakan pemerintah ini akan memberikan tekanan tersendiri kepada pegawai. Dengan semakin naiknya bahan pokok dan kebutuhan lainnya yang tidak diiringi dengan kenaikan gaji yang sesuai akan memicu pegawai bersikap malas dalam bekerja bahkan melakukan tindakan yang berpotensi ke arah kecurangan (fraud). Contoh dari hal ini adalah tindakan dokter yang memberikan diagnosa yang tidak perlu dan pelaksanaan upcoding. Memberikan diagnosa dan upcoding adalah isu-isu yang berkaitan dengan profesional medis dan pasien yang dilakukan atas dasar berbagai alasan. Coders medis menetapkan kode-kode tertentu, kode disebut CPT (terminologi prosedural saat ini), yang memberikan informasi tentang layanan atau prosedur yang telah dilakukan oleh penyedia layanan kesehatan. Jika kode yang dicatat adalah untuk layanan tingkat yang lebih tinggi atau prosedur dari apa yang didokumentasikan dalam grafik pasien, ini disebut sebagai upcoding. Dokter biasanya memberikan diagnosa apa yang mereka temukan sedangkan petugas coder memberikan kode sesuai dengan diagnosa yang dituliskan oleh dokter. Akan tetapi, kerap didapati peristiwa upcoding karena dokter tidak memiliki pendidikan terkait coding, meskipun terkadang hal ini pun merupakan perbuatan yang disengaja. Jika seorang dokter dalam prakteknya melakukan upcoding, diperlukan keterlibatan pihak ketiga yang independen untuk melakukan review grafik guna mengkonfirmasi atau menyingkirkan kecurigaan. Namun, baik pemberian diagnosa yang tidak perlu, maupun upcoding yang dibuat oleh dokter, keduanya dianggap sebagai bentuk tindakan fraud (Kemenkes, 2015, Charles, 2015).

Tekanan yang dialami pegawai bukan berasal dari tekanan internal rumah sakit saja tapi juga dari tekanan eksternal rumah sakit misalnya kebutuhan keluarga dan gaya hidup, gaji untuk pegawai secara keseluruhan take home pay (gaji pokok, remunerasi dan lauk pauk) untuk pegawai Perjanjian Kerja Waktu Tertentu (PKWT) berkisar Rp 3.000.000 - Rp 4. 000. 000), Pegawai Tetap berk- isar Rp. 5. 000. 000 - Rp. 7.000 .000 sedangkan Pegawai Negeri Sipil (PNS) Gol 2c berkisar Rp 5.300.000 - Rp 7.500.000) setiap bulan. Pemberian gaji yang kurang dapat memberikan tekanan kepada pegawai di mana pegawai yang bekerja merasa pekerjaannya tidak diindahkan dengan pemberian gaji yang sesuai.

Hal ini diperkeruh dengan kegiatan pelayanan pasien di RSUP Nasional Cipto Mangunkusumo yang setiap harinya menerima pasien BPJS rawat jalan rata - rata 1500 - 2300 selama pelayanan yang dimulai dari pukul 07.00 WIB. Kebijakan ini tentu saja akan memberikan tekanan tersendiri kepada pegawai, misalnya pegawai yang bersangkutan akan merasa gajinya tidak sesuai dengan pekerjaan yang mereka kerjakan.

Tekanan menyebabkan seseorang melakukan kecurangan. Tekanan dapat berupa bermacam-macam termasuk gaya hidup, tuntutan ekonomi, dan lain-lain. Tekanan paling sering datang dari adanya tekanan kebutuhan keuangan. Kebutuhan ini seringkali dianggap kebutuhan yang tidak dapat dibagi dengan orang lain untuk bersama-sama menyelesaikannya sehingga harus diselesaikan secara tersembunyi dan pada akhirnya menyebabkan terjadinya kecurangan. Menurut SAS No.99, terdapat empat jenis kondisi yang umum terjadi pada tekanan yang dapat mengakibatkan kecurangan, yaitu financial stability, external pressure, personal financial need, dan financial targets.

Financial stability adalah keadaan yang menggambarkan kondisi keuangan perusahaan dalam kondisi stabil. Contoh faktor risiko yang dimaksud adalah perusahaan mungkin memanipulasi laba ketika stabilitas keuangan atau profitabilitasnya terancam oleh kondisi ekonomi. External pressure adalah tekanan yang berlebihan bagi manajemen untuk memenuhi persyaratan atau harapan dari pihak ketiga. Contoh faktor risikonya adalah ketika perusahaan menghadapi adanya tren tingkat ekspektasi para analis investasi, tekanan untuk memberikan kinerja terbaik bagi investor dan kreditor yang signifikan bagi perusahaan atau pihak eksternal lainnya. Personal financial need adalah kondisi ketika keuangan perusahaan turut dipengaruhi oleh kondisi keuangan para eksekutif perusahaan. Contoh faktor risikonya seperti kepentingan keuangan oleh manajemen yang signifikan dalam entitas, manajemen memiliki bagian kompensasi yang signifikan yang bergantung pada pencapaian target yang agresif untuk harga saham, hasil operasi, posisi keuangan, atau arus kas manajemen menjaminkan harta pribadi untuk utang entitas. Financial targets adalah tekanan berlebihan pada manajemen untuk mencapai target keuangan yang dipatok oleh direksi atau manajemen. Contoh faktor risiko yang dimaksud adalah perusahaan mungkin memanipu- 
lasi laba untuk memenuhi prakiraan atau tolok ukur para analis seperti laba tahun sebelumnya.

\section{Pengaruh Tekanan Terhadap Potensi Fraud}

Berdasarkan analisis internal control dari RSUP Nasional DR Cipto Mangunkusumo, dapat dilihat bahwa kesempatan untuk melakukan tindakan fraud dirasa sangat sulit karena sudah jelas dan ada pemisahan tugas dalam bekerja, khususnya di bagian memberikan kode diagnosa penyakit, input ke sistem INA-CBGs dan melakukan verifikator internal, berbeda dengan rumah sakit pada umumnya. Pada dasarnya, seluruh pekerjaan tersebut dikerjakan oleh satu orang karena menurut kontrol dari team antifraud di rumah sakit, pekerjaan tersebut sangat berpotensi melakukan tindakan fraud. Meskipun surat tugas dan fungsi atas tanggung jawab sudah diterapkan demikian namun terdapat kekurangan dan kelebihan tersendiri. Kebijakan tidak akan dijalankan jika individu tidak peduli dan tidak mau menjalankan aturan yang disepakati untuk kepentingan bersama.

Faktor individu merupakan kendala yang sering dijumpai. Sifat manusia yang serakah dan kebutuhan hidup yang terus meningkat mendorong seseorang untuk mencari cara untuk mendapatkan uang dengan cara apapun walaupun dengan cara yang tidak dibenarkan. Sebaik apapun sistem dan kebijakannya, tidak akan efektif jika individunya tidak menjalankan dengan baik. Maka diperlukan adanya perekrutan pegawai yang tepat untuk mencegah pelaksanaan KKN (Korupsi , Kolusi dan Nepotisme) sehingga pegawai yang mengikuti perekrutan yang jujur dapat mencegah potensi terjadinya fraud. Organisasi harus membangun adanya proses, prosedur dan pengendalian yang bermanfaat dan menempatkan karyawan dalam posisi tertentu agar mereka tidak dapat melakukan kecurangan dan efektif dalam mendeteksi kecurangan seperti yang dinyatakan dalam SAS No.99. SAS No.99. Di dalamnya disebutkanbahwa peluang pada financial statement fraud dapat terjadi pada tiga kategori kondisi, yaitu nature of industry, ineffective monitoring, dan organizational structure. Nature of industry adalah berkaitan dengan munculnya risiko bagi perusahaan yang berkecimpung dalam industri yang melibatkan estimasi dan pertimbangan yang signifikan jauh lebih besar. Contoh faktor risiko: penilaian persediaan mengandung risiko salah saji yang lebih besar bagi perusahaan yang persediaannya tersebar di banyak lokasi. Risiko salah saji persediaan ini semakin meningkat jika persediaan itu menjadi usang. Ineffective monitoring adalah keadaan di mana perusahaan tidak memiliki unit pengawas yang efektif memantau kinerja perusahaan. Contoh faktor risiko: adanya dominasi manajemen oleh satu orang atau kelompok kecil, tanpa kontrol kompensasi, tidak efektifnya pengawasan dewan direksi dan komite audit atas proses pelaporan keuangan dan pengendalian internal dan sejenisnya. Organizational Structure adalah struktur organisasi yang kompleks dan tidak stabil. Contoh faktor risiko: struktur organisasi yang terlalu kompleks, perputaran personil perusahaan seperti senior manajer atau direksi yang tinggi.

\section{Pengaruh Rasionalisasi (Pembenaran) Terhadap Po- tensi Fraud}

Rasionalisasi (rationalization), yaitu konflik internal dalam diri pelaku sebagai upaya untuk membenarkan tindakan fraud yang dilakukannya. Rasionalisasi ini terkait dengan environment control dalam lingkungan badan usaha. Sebuah pengendalian yang baik membutuhkan sebuah lingkungan yang menetapkan suatu keadaan di mana perilaku yang tepat dapat dilakukan, di manakaryawan mengerjakan pekerjaan sesuai tugasnya dan menerima gaji yang sesuai dan jujur. Pengendalian yang baik seperti punishment yang jelas bagi karyawan akan mengurangi tindakan yang berpotensi fraud (kecurangan). Tidak ada penugasan yang jelas dari pimpinan atau direktur atas pekerjaan yang harus dilakukan pegawai akan menimbulkan budaya saling ketergantungan terhadap pegawai ataupun saling tukar menukar pekerjaannya. Misalnya, proses pemberian kode diagnosa seharusnya dilakukan oleh petugas koder yang bertanggung jawab dalam memberikan kode yang sesuai dengan diagnosa. Namun, petugas tersebut bergantian bahkan mengerjakan pekerjaan orang lain seperti mengerjakan lemburan, ataudokter yang sedang menjalani pendidikan diberi kewenangan untuk memberikan diagnosa yang seharusnya dikerjakan oleh DPJP yang berhalangan karena sibuk. Hal ini membuat kemungkinan terjadinya fraud semakin besar.

Kebijakan yang memberikan kebebasan untuk memilih pekerjaan yang akan dilakukan atau ada surat tugas namun tidak sesuai dengan yang dilakukan memiliki kelebihan dan kelemahan sendiri. Kelebihannya yaitu pegawai akan merasa memiliki kebebasan, menambah ilmu dan merasa dipercayai melakukan pekerjaan yang tidak terlalu sesuai dengan keahliannya. Sedangkan kelemahannya yaitu pegawai akan melakukan pekerjaan dengan kurangnya rasa tanggung jawabdan pimpinan pun akan sulit untuk memberikan sanksi karena karyawan mengerjakan hal yang tidak sesuai dengan tugasnya. Hal ini bahkan akan memberikan dampak yang sangat buruk terhadap unit tempat kerja dan rumah sakit.

Kebiasaan memberikan kepercayaan terhadap salah satu pegawai juga akan memunculkan rasionalisasi karena pegawai akan merasa dirinya lebih baik dibandingkan dengan karyawan yang lain. Hal ini dapat menurunkan 
hubungan baik antar pegawai. Pegawai yang dipercayai juga akan berpotensi melakukan tindakan fraud karena dirinya merasa sebagai orang kepercayaan pimpinan, ia berpikir perbuatannya benar selama pimpinan tidak mengetahuinya. Beberapa pembenaran berikut ini sering digunakan oleh para pelaku tindakan fraud (fraudsters) yaitu : the organization owes it to me, I am only borrowing the money-I will pay it back, nobody will get hurt, I deserve more, it's for a good purpose, we'll fix the books as soon as we get over this financial difficulty, something has to be sacrificed-my integrity or my reputation (Albrecht, 2012).

Rasionalisasi juga dapat berpotensi kepada pegawai yang bekerja sudah lama terutama yang sudah menjadi pegawai negeri sipil (PNS) karena beranggap bahwa dirinya berhak mendapatkan lebih karena masa kerja sudah lama dan merasa melakukan tindakan fraud bukan masalah. Menurut SAS No.99 rasionalisasi pada perusahaan dapat diukur dengan siklus pergantian auditor, opini audit yang didapat perusahaan tersebut serta keadaan total akrual dibagi dengan total aktiva.

\section{Kendala Terhadap Kebijakan Pencegahan Fraud di Rumah Sakit}

Salah satu kendala dalam pelaksanaan kebijakan pencegahan fraud adalahbelum adanya kekuatan hokum dalam pemberantasan fraud. KPK belum memikirkan sampai penyelidikan, OJK pun masih dalam mencari keuntungan ekonomi. Pencegahan, pendeteksian dan penginvestigasian fraud dilakukan dalam upaya untuk mengeliminasi tindakan fraud. Persepsi aktor dari pemegang kebijakan di rumah sakit dan dari team anti fraud dalam kebijakan pencegahan fraud tidak bermain - main, mereka sangat fokus terhadap kebijakan tersebut. Upaya untuk mengurangi tindakan fraud dibagi kedalam 3 (tiga) fase. Pada fase pertama yaitu fase pencegahan tindakan fraud. Cara yang paling efektif adalah melalui perubahan perilaku dan budaya organisasi yang memberikan perhatian lebih atas tindakan kecurangan. Upaya yang dilakukan adalah melalui struktur corporate governance, tone at the top, penentuan tujuan yang realistis dan kebijakan serta prosedur yang dapat mencegah tindakan penyimpangan (Singleton, 2010).

\section{Kesimpulan dan Saran}

\section{Kesimpulan}

1. Potensi fraud di RSUP Nasional DR Cipto Mangunkusumo dapat terjadi karena lemahnya pengendalian internal.

2. Potensi fraud yang terjadi di RSUP Nasional DR Cipto Mangunkusumo dapat terjadi di seluruh bagian berdasasarkan alur penerimaan pasien jaminan kesehatan nasional.

3. Potensi fraud di RSUP Nasional DR Cipto Mangunkusumo dapat terjadi karena adanya tekanan, kesempatan dan rasionalisasi.

4. Potensi fraud di RSUP Nasional DR Cipto Mangunkusumo juga didukung oleh komitmen dari manajemen puncak untuk merealisasikan anggaran dan mempertanggungjawabkannya dengan tepat waktu.

\section{Saran}

\section{Untuk Rumah sakit (Provider) :}

1. Perlu perbaikan control activity pada semua aktivitas yang terdapat pada pengelolaan JKN

2. Sebaiknya RSUP Nasional DR Cipto Mangunkusumo khusunya bagian Team Anti-Fraud agar dapat menilai dan mengelola risiko - risiko yang mungkin terjadi potensi tindakan fraud datang.

3. Perlunya anggaran khusus untuk pelaksanaan pencegahan terjadinya tindakan potensi fraud untuk mendapatkan hasil dan manfaat yang besar.

4. Perlunya perbaikan internal di RSUP Nasional DR Cipto Mangunkusumo dalam membuat kebijakan yang berpotensi melakukan tindakan fraud.

\section{Untuk perusahaan asuransi :}

1. Perlu melakukan sosialisasi terkait kebijakan pencegahan fraud di rumah sakit (FKRTL).

2. Perlu melakukan sosialisasi terkait ketentuan tim anti-fraud di rumah sakit.

3. Perlu mengadakan kerjasama dengan rumah sakit, untuk memudahkan sosialisasi kebijakan pencegahan fraud.

3. Untuk pasien :

1. Perlunya pemahaman pasien tentang tindakan fraud terhadap prosedur pelayanan JKN.

2. Perlunya pemahaman pasien terhadap resiko tindakan fraud yang diperoleh terhadap sanksi yang akan diterima..

3. Kesadaran pasien akan hak dan kewajiban berdasarkan ketentuan sebagai peserta JKN.

\section{Daftar Pustaka}

Albrecht, W. S. 2012. Fraud Examination, Fourth Edition, South-Western., USA.

Anonymous 2009. The National Care Anti - Fraud Association Signs Memorandum Of Understanding With UK-base Health Insurance Counter Fraud Group (HICFG).

Charles, P. 2015. Sepuluh Skema Fraud Dalam Asuransi Kesehatan.

Coffin, B. 2003. Breaking The Silence On White Collar Crime. Risk Management 40.

Data, S. B. O. I. 2002. Health Insurance Of American Asso- 
ciation Washington. America.

Gepp, A., Kumar, K. \& Bhattacharya, S. 2015. The Fraud Detection Triangle: A new framework for selecting variables in fraud detection research.

Ginting, R. C. 2007. RE: Kecurangan (Fraud) Dalam Jaminan/Asuransi Kesehatan.

KEMENKES 2015. Peraturan Menteri Kesehatan Republik Indonesia Nomor 36 Tahun 2015 Tentang Pencegahan Kecurangan (Fraud) Dalam Pelaksanaan Program Jaminan Kesehatan Pada Sistem Jaminan Sosial Nasional. In : Menteri Hukum Dan Hak Asasi Manusia Republik Indonesia.

Shi, Y., Sun, C., Li, Q., Cui, L., Yu, H. \& Miao, C. 2016. A Fraud Resilient Medical Insurance Claim System.

Singleton, S. 2010. Fraud Auditing and Forensic Accounting, Fourth Edition Wiley Corporate F\&A.

Skousen, C. J., Smith, K. R. \& Wright, C. J. 2009. Detecting and predicting financial statement fraud: The effectiveness of the fraud triangle and SAS No. 99. Advances in Financial Economics, 13, 53-81.

Sugiono 2009. Metode Penelitian Kuantitatif Kualitatif dan
RerD, Alfabeta, Bandung.

Thabrany, H. 2014. Jaminan Kesehatan Nasional, Jakarta, PT RajaGrafindo Persada.

WHO 2000. The Word Health Refort 2000. Health System: Improving Performance, Geneva, Word Health Organization.

Wiyono, M. 2014. Mengenal Potensi Fraud pada Program Jaminan kesehatan Nasional (JKN). Kompasiana manajemen.

WWW.ACFE.COM. diunduh tanggal 19 April 2016 Association of Certified Fraud Examiner [Online]. www. acfe.com. [Accessed].

Yaslis, I. 2003. Asuransi Kesehatan Review Utilisasi Manajemen Klaim dan Fraud(kecurangan asuransi kesehatan) Jakarta Fakultas kesehatan masyarakat universitas Indonesia.

Yaslis, I. 2015. Fraud dalam Jaminan Kesehatan Nasional (kumpulan tulisan yaslis ilyas) CV, Usaha Prima, Jakarta Tiariaji Press. 